\title{
Comparative Study of Neem Seed Oil and Watermelon Seed Oil as Quenching Media for Thermal Processing of Steel.
}

\author{
S. A. Salihu ${ }^{1}$; Y. I. Sulaiman ${ }^{1}$, S. B. Hassan ${ }^{2}$ \\ ${ }^{I}$ Department of Metallurgical and Materials Engineering Technology, Waziri Umaru Federal Polytechnic, \\ Birnin - Kebbi, Kebbi State, Nigeria \\ ${ }^{2}$ Department of Metallurgical and Materials Engineering, Ahmadu Bello University, Zaria, Kaduna State, \\ Nigeria
}

\begin{abstract}
In this work, comparative analysis of two biodegradable oils (neem seed oil and watermelon seed oil) were compared with conventional quenching oil (mineral oil) for heat treatment of steel. The plain carbon steel of $0.37 \%$ Co $25 \mathrm{~mm}$ diameter was austenitized at different temperatures $\left(800,830,850,880\right.$, and $\left.900^{\circ} \mathrm{C}\right)$ for $1 \mathrm{hr}$, quenched separately in these respective oils and tempered at different tempering temperatures (250, $270,300,330,350$ and $400^{\circ} \mathrm{C}$ ) for $1 \mathrm{hr}$, thereafter cooled to room temperature in these oils. The microstructure resulted by different conditions have been correlated with mechanical properties through optical microscopy. The results indicate that the mechanical properties and microstructural features are affected by tempering temperature and austenitizing temperature on both quenchants. The tensile strength, hardness and retained austenite of tempered samples drop as the tempering temperature increased. However, the impact strength increases with increasing tempering and austenitizing temperature, indicating improvement of ductility. Microstructural observations reveal that the carbide precipitates have a plate-like structure at lower tempering temperatures, but are spheroid-like at high temperatures on both quenchants, but less pronounced on watermelon oil.
\end{abstract}

Keywords: Quenching media, heat treatment, mechanical properties, quenching, tempering,

\section{Introduction}

Quenching media are widely applied for heat treatment processes of engineering materials in order to achieve enhanced properties (Rajan and Sharma, 1994, Salihu, 2011). There are wide variety of quenchants used for industrial heat treatment which include; water, brine solutions, mineral and vegetable oils, aqueous polymers, salt baths and fluidized beds (Novikov, 1980 and Callister, 2008). Water though abundant and low cost has the drawback of inducing crack or dimensional changes on the quenched component due to its high cooling rate and oil has the problem of not inducing enough hardness. Polymer quenchant though can provide severity between those of water and oil has the problem of varying concentration during the quenching process and it is also more expensive. Brine produces more quenching severity than water; but it also has a problem of corrosive attack on the components and the equipment used for the quenching (Tagaya, Tamura,(1954), Totten, Howes,(1997), Fujimura, Sato, (1963)) Quenching, as one of the most important processes of heat treatment, that can improve the performance of steel greatly, but an important side effect of quenching is the formation of thermal and transformational stresses that cause changes in size and shape that may result in cracks (Totten, Maurice, Hawes, 1997). The technical challenge of quenching is therefore, to select the quenching medium and process that will minimize the various stresses that develop within the part to reduce cracking and distortion.(Tagaya, and Tamura, 1954).

Many types of vegetables oils have been traditionally used in food processing and body formulation, but many researchers have suggested their economic usefulness as industrial fluids. For example, palm oil, cottonseed oil, peanut oil, sunflower oil, canola oil, soybean and corn oils have been experimentally tested and found to an excellent quenchants economically, environmentally, and performance resulting to less distortion (Tagaya, Tamura, 1954).

Neem seeds and watermelon seeds are some of the species which grow abundantly in Northern Nigeria, but has not been properly exploited technologically and economically. There were very few researches of using neem seed and watermelon seed oils as quenching fluids. However, while neem and watermelon species have been used for medical and cosmetic purposes on a small scale respectively. In an attempt to find more areas of their usefulness, their oils were extracted and tested as quenching media for heat treatment of medium carbon steel.

Neem, botanically known as Azadirachta Indica, is a soft natural insecticide, safe, eco-friendly and biodegradable. But, neem is also known for its bitter taste due to a group of organic compounds called tetranortriterpenoids or more specifically, limonoids (Hassan et al, 2011). Watermelon seed oil known as Ootanga oil and Kalahari oil is highly nutritive oil used in cosmetic products and pharmacy medicine. 
There therefore a need for the development of a quenching medium with good economics like water having less severity of quench and yet producing appreciable hardening. Hence this work is aimed at investigating the suitability of using biodegradable neem oil and watermelon seed oil that are cheaper, ecofriendly and less pollutants than mineral oil as a quenching medium for hardening of medium carbon steel.

\section{Materials}

Materials used in this study are: medium carbon steel, Neem seeds oil bought from National Research Institute for Chemical Technology (NRICT) Zaria, Watermelon seeds bought from local market in Birnin Kebbi, and the oil was extracted using traditional way while SAE 40 engine oil used as standard quenching medium. The chemical composition of the steel used is shown in Table 2.1 while Table 2.2 shows properties of Neem seed oil and watermelon seed oil and SAE 40 engine oil.

Table 2.1 Chemical composition of the material used.

\begin{tabular}{|l|l|l|l|l|l|l|l|}
\hline $\mathrm{C}$ & $\mathrm{Mn}$ & $\mathrm{Si}$ & $\mathrm{Zn}$ & $\mathrm{P}$ & $\mathrm{S}$ & $\mathrm{Cu}$ & $\mathrm{Fe}$ \\
\hline 0.37 & 0.64 & 0.42 & 0.08 & 0.013 & 0.012 & 0.22 & Bal \\
\hline
\end{tabular}

Table 2.2 Some physicochemical properties of oils used

\begin{tabular}{|c|c|c|c|c|c|c|c|c|}
\hline $\begin{array}{l}\text { Type of } \\
\text { oil }\end{array}$ & $\begin{array}{l}\text { Specific } \\
\text { gravity (g) }\end{array}$ & $\begin{array}{l}\text { Saponification } \\
\text { value }\end{array}$ & $\begin{array}{l}\text { Viscosity at } \\
40^{0} \mathrm{C},\left(\mathrm{mm}^{2} \mathrm{~s}^{-1}\right)\end{array}$ & $\begin{array}{l}\text { Flash point, } \\
\left({ }^{0} \mathrm{C}\right)\end{array}$ & $\begin{array}{l}\text { Iodine } \\
\text { value }\end{array}$ & $\begin{array}{l}\text { Acid } \\
\text { value }\end{array}$ & $\begin{array}{l}\text { Boiling } \\
\text { point, }\left({ }^{0} \mathrm{C}\right)\end{array}$ & Colour \\
\hline $\begin{array}{l}\text { Neem } \\
\text { seed }\end{array}$ & 0.915 & $211.15 \mathrm{mg}$ & 20.78 & 180 & 74.9 & 13.945 & 175 & $\begin{array}{l}\text { Dark } \\
\text { green } \\
\text { brownish }\end{array}$ \\
\hline $\begin{array}{l}\text { Waterm } \\
\text { elon } \\
\text { seed }\end{array}$ & 0.8786 & 192.5 & 8.31 & 186 & 121.8 & 3.08 & 144 & $\begin{array}{l}\text { Golden } \\
\text { yellow }\end{array}$ \\
\hline
\end{tabular}

Neem seed oil, watermelon seed oil and SAE 40 engine oil were used separately for quenching and hardening throughout the experiments. After suitably heating the specimens to various austenitizing temperatures, they were quenched in these oils and immediately after cooling to room temperature they were reheated to a series of temperatures between $250^{\circ} \mathrm{C}$ and $400^{\circ} \mathrm{C}$.

After tempering, the specimens were cooled to room temperature and mechanical tests were conducted at room temperature as indicated below.

\subsection{Mechanical Tests}

The mechanical properties of heat treated carbon steel specimens were determined by tensile, impact and hardness tests.

\subsubsection{Tensile Test}

The tensile test was carried out on the low carbon steel specimens that have been subjected to the under listed heat treatment as indicated in Table 2.3. Hounsfield tensiometer testing machines was used to carry out all the tensile tests. Figure 1 shows the dimensions of standard test bar used in these tests. The specimens were machined to the standard diameter size 5mm as specified in BS 2789:2002.

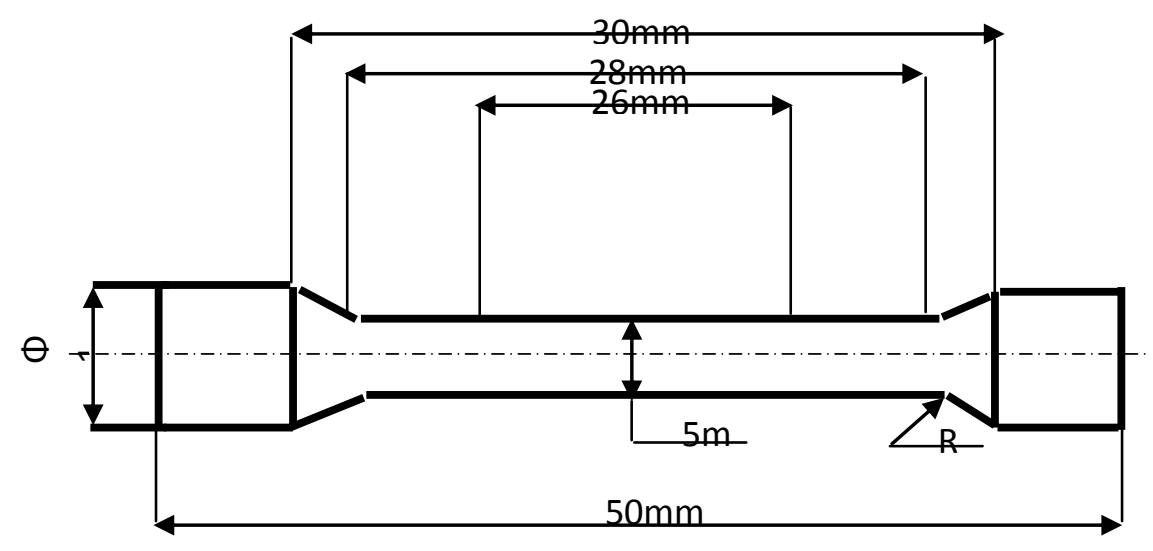

Figure.1 Standard size Tensile Test Specimen used 
Table 2.3 Mechanical Properties of various samples used

\begin{tabular}{|l|l|l|l|l|l|}
\hline Quenchant & Heat treatment & $\begin{array}{l}\text { Tensile } \\
\text { strength, } \\
\text { MPa }\end{array}$ & $\begin{array}{l}\text { Yield } \\
\text { strength, } \\
\text { MPa }\end{array}$ & $\begin{array}{l}\text { Hardness, } \\
\text { HRA }\end{array}$ & $\begin{array}{l}\text { Impact } \\
\text { strength, } \\
\text { J }\end{array}$ \\
\hline SAE 40 & Quenched at $800^{\circ} \mathrm{C}$ and tempered at $250^{\circ} \mathrm{C}$ & 2077 & 1855 & 63.2 & 22 \\
& Quenched at $830^{\circ} \mathrm{C}$ and tempered at $270^{\circ} \mathrm{C}$ & 1998 & 1678 & 60.0 & 24 \\
& Quenched at $850^{\circ} \mathrm{C}$ and tempered at $300^{\circ} \mathrm{C}$ & 1964 & 1637 & 58.5 & 25 \\
& Quenched at $870^{\circ} \mathrm{C}$ and tempered at $330^{\circ} \mathrm{C}$ & 1950 & 1628 & 57.4 & 27 \\
& Quenched at $900^{\circ} \mathrm{C}$ and tempered at $350^{\circ} \mathrm{C}$ & 1932 & 1602 & 55.8 & 30 \\
& Quenched at $900^{\circ} \mathrm{C}$ tempered at $400^{\circ} \mathrm{C}$ & 1904 & 1572 & 54.6 & 31 \\
\hline Neem oil & Quenched at $800^{\circ} \mathrm{C}$ and tempered at $250^{\circ} \mathrm{C}$ & 2122 & 2014 & 68.7 & 23 \\
& Quenched at $830^{\circ} \mathrm{C}$ and tempered at $270^{\circ} \mathrm{C}$ & 2082 & 1905 & $64 . .7$ & 25 \\
& Quenched at $850^{\circ} \mathrm{C}$ and tempered at $300^{\circ} \mathrm{C}$ & 2058 & 1876 & 63.1 & 27 \\
& Quenched at $870^{\circ} \mathrm{C}$ and tempered at $330^{\circ} \mathrm{C}$ & 2028 & 1823 & 61.2 & 28 \\
& Quenched at $900^{\circ} \mathrm{C}$ and tempered at $350^{\circ} \mathrm{C}$ & 1995 & 1798 & 57.9 & 30 \\
& Quenched at $900^{\circ} \mathrm{C}$ and tempered at $400^{\circ} \mathrm{C}$ & 1976 & 1723 & 55.4 & 31 \\
\hline Watermelon & Quenched at $800^{\circ} \mathrm{C}$ and tempered at $250^{\circ} \mathrm{C}$ & 2031 & 1854 & 59.0 & 20.5 \\
& Quenched at $830^{\circ} \mathrm{C}$ and tempered at $270^{\circ} \mathrm{C}$ & 2002 & 1796 & 57.4 & 22.0 \\
& Quenched at $850^{\circ} \mathrm{C}$ and tempered at $300^{\circ} \mathrm{C}$ & 1978 & 1632 & 56.2 & 23.1 \\
& Quenched at $870^{\circ} \mathrm{C}$ and tempered at $330^{\circ} \mathrm{C}$ & 1945 & 1598 & 55.8 & 25.2 \\
& Quenched at $900^{\circ} \mathrm{C}$ and tempered at $350^{\circ} \mathrm{C}$ & 1916 & 1538 & 54.6 & 26.0 \\
& Quenched at $900^{\circ} \mathrm{C}$ and tempered at $400^{\circ} \mathrm{C}$ & 1889 & 1494 & 52.8 & 27.6 \\
\hline
\end{tabular}

\subsubsection{Impact Test}

The impact test was carried out on the carbon steel specimens subjected to the under listed heat treatment conditions as indicated in Table 2.3. A 150 Joules capacity Avery Denison Charpy machine with a sticking velocity of $5.24 \mathrm{~m} / \mathrm{sec}$. was used to carry out the impact tests. Figure 2 .shows the dimensions of standard test bar used in these tests. The specimen is fixed on horizontal position and the hammer strikes the impact specimen on the notched face. The energy absorbed is a measure of the impact strength of the material. The results of impact test are shown in Table 2.3.

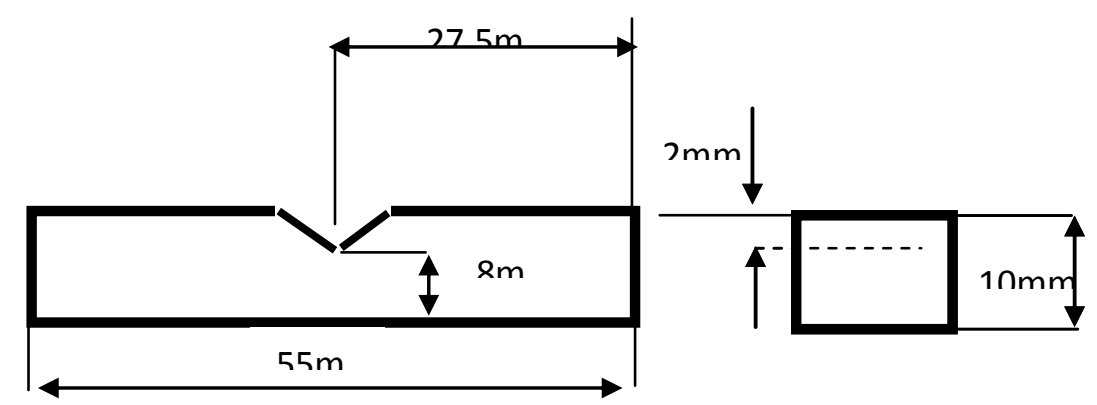

Figure 2.Impact sample dimensions used

\subsubsection{Hardness Test}

In order to assess the mechanical properties of samples, each sample was subject to a hardness test using a Rockwell indenter, under a load of $150 \mathrm{~kg}$ for HRA scale for 10 seconds. Each sample was tested 10 times in order to get an accurate value by averaging out anomalies. after hardness tests had been carried out, each sample was re grinded and polished in preparation for optical microscopy. The result of hardness test is shown in Table 2.3

\subsubsection{Metallography}

Metallographic examination was carried out on the carbon steel specimens. Standard techniques for specimens preparation for the microstructure observation were adopted. The samples were mounted on bakelite using silicon carbide abrasive papers (240 to 600 grits sizes). Following the polishing of specimens on a rotating disc and subsequent surface cleaning, etching of the polished specimen was done using $2 \%$ Nital (2\% Nitric acid, $\mathrm{HNO}_{3}$, in ethyl alcohol) for $15-30$ seconds to develop the structure. The structures obtained were photographed, and are shown in Figures 3 to 6.

\section{Results and Discussion.}

\subsection{Effect of quenching media on microstructure and mechanical properties}

The three quenching media under investigation have shown influence on the microstructural formation and mechanical properties of the steel because of their different physicochemical properties. Figure 3 (a). shows 
the microstructure of the as-received medium carbon steel which reveals the presence of ferrite, massive pearlite and inclusions. As explained by Novikov, (1980), different quenching media have significant role in determining the final structure of an alloy because of different cooling rates. The quenching media under investigation have different cooling rate . Of the oils under investigation, watermelon oil is the most severe and mineral oil the least. Figure 3 shows microstructures of three samples that underwent the same heat treatment conditions (austenitized at $800^{\circ} \mathrm{C}$, tempered at $250^{\circ} \mathrm{C}$ ) but with different quenching media. The results of structural formations show different proportions of martensites, retained austenite and carbides. Figures 4 to 6 also show that with increase of tempering temperature, structural transformations were observed revealing more bainitic structure, less retained austenite and martensite more especially with samples that were tempered at 300 to $400^{\circ} \mathrm{C}$ in mineral oil and watermelon oil.

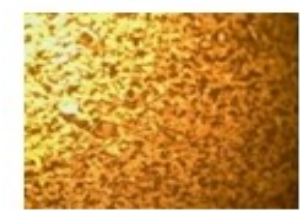

a)

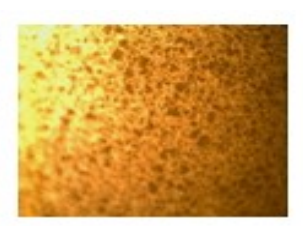

b)

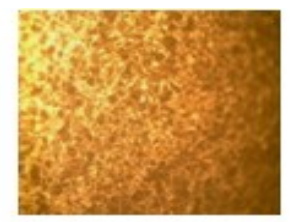

c).

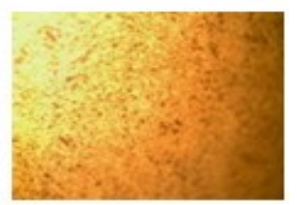

d)

Fig. 3 Microstructure of medium carbon steel a) as-received; austenitized at $800^{\circ} \mathrm{C}$, quenched and tempered at $250^{\circ} \mathrm{C}$ b) (mineral oil; c) watermelon oil; d) neem oil x200.

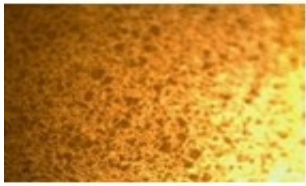

a)

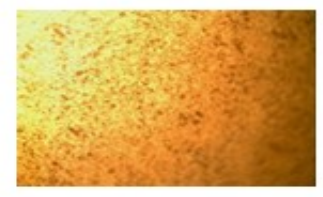

b)

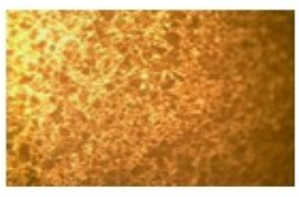

c)

Figure 4. Microstructures of medium carbon steel austenitized at $850^{\circ} \mathrm{C}$, quenched and tempered at $250^{\circ} \mathrm{C}$ a) (mineral oil; b) neem oil; c) watermelon oil x200.

Figure 4 shows microstructures of three samples that underwent another set of heat treatment conditions (austenitized at $850^{\circ} \mathrm{C}$, tempered at $300^{\circ} \mathrm{C}$ ) with quenching media, showing how retained austenite was transformed to another structure, bainite. As observed, the presence of bainite is more on sample tempered in watermelon oil and mineral oil than neem oil sample. There were significant decrease in hardness and tensile strength, but with improvement in impact strength. Figures 5 and 6 show the presence of less martensite and retained austenite, more bainite for samples tempered in watermelon and mineral oils than neem oil. At the same time it shows that increasing tempering temperature to $400^{\circ} \mathrm{C}$ brings about a decrease in hardness and tensile strength for both samples.

a)

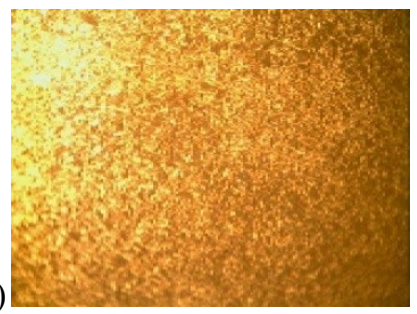

b)

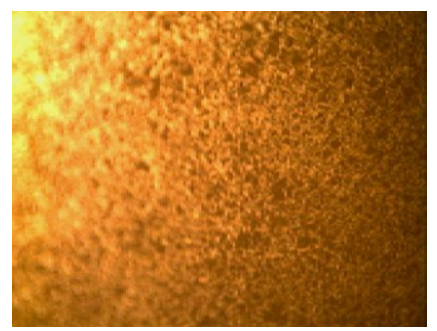

c)

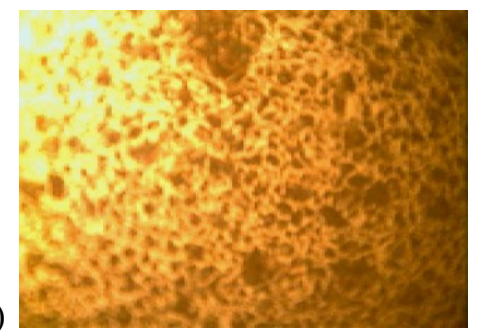

Figure 5 Microstructures of samples that were austenitized at $900^{\circ} \mathrm{C}$, tempered at $300^{\circ} \mathrm{C}$ with the tree quenching media. a) mineral oil; b) neem oil; c) watermelon oil x200. 
a)

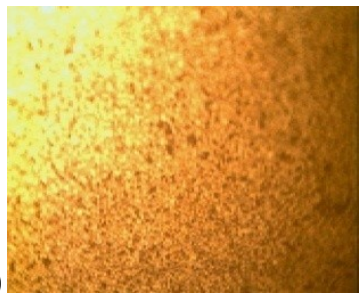

b)

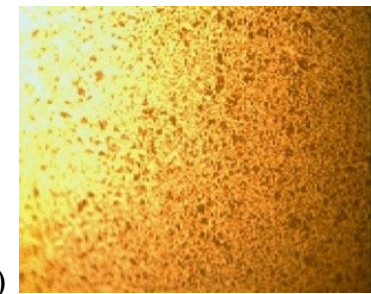

(C)

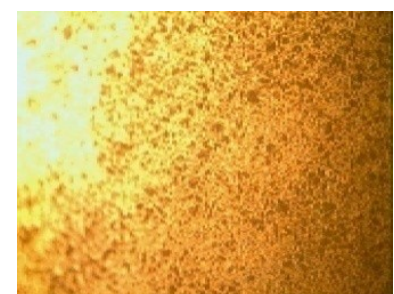

Fig. 6 Microstructures of medium carbon steel austenitized at $900^{\circ} \mathrm{C}$, quenched and tempered at $350^{\circ} \mathrm{C}$ a) (mineral oil; b) neem oil; c) watermelon oil x200.

\subsection{Effect of tempering temperature on microstructure and mechanical properties}

The variation on the mechanical properties of carbon steel at different tempering temperatures in the three quenching media are shown in Figures 7 to 15. It was observed that, as the tempering temperature increases both the tensile strength, yield strength and hardness decrease. However, in contrast, the impact strength increase by increasing the tempering temperature. As observed from Figures 7 to 12 that for quenched and tempered samples, the strength and hardness values decrease with higher tempering temperature and that impact strength increases. Higher tensile strength is achieved by tempering the steel at lower temperature. This is to be expected because the carbon is diffusing out of the martensite and forming small sphere-like particles of $\mathrm{Fe}_{3} \mathrm{C}$. As the tempering temperature rises, the rate of diffusion increases, which would allow larger $\mathrm{Fe}_{3} \mathrm{C}$ particles. Larger particles results in less phase boundary area, lower strength, and higher impact strength. The experimental data did match up with the literature data (ASM, 1997).

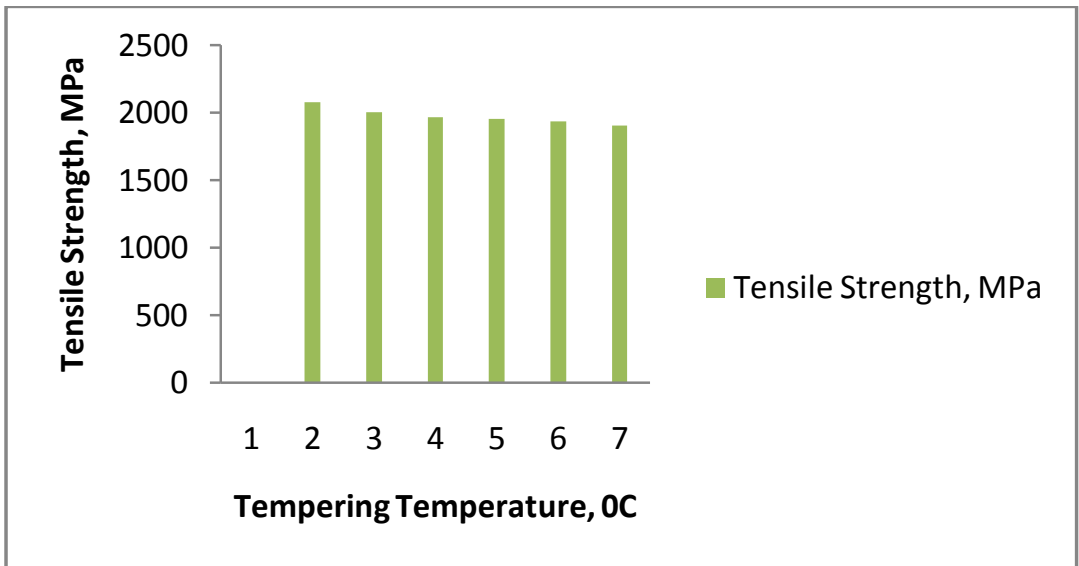

Fig. 7. Influence of the tempering temperature on tensile strength of medium carbon steel quenched and tempered in mineral oil.

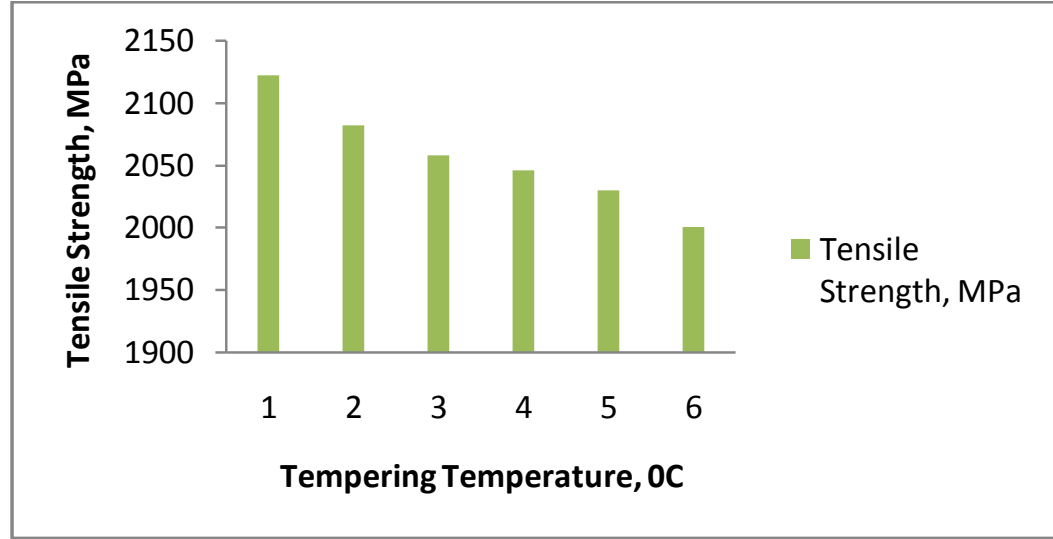

Fig. 8. . Influence of the tempering temperature on tensile strength of medium carbon steel quenched and tempered in neem oil. 


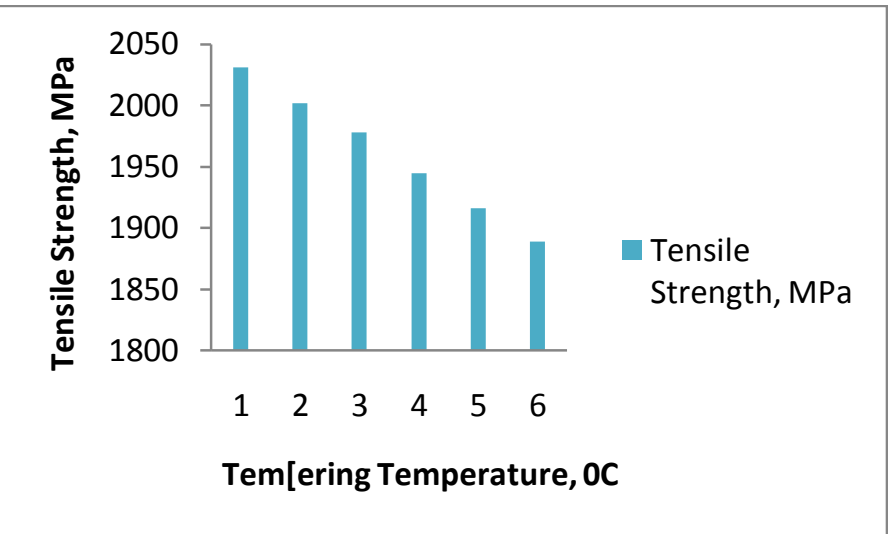

Fig. 9 Influence of the tempering temperature on tensile strength of medium carbon steel quenched and tempered in watermelon oil.

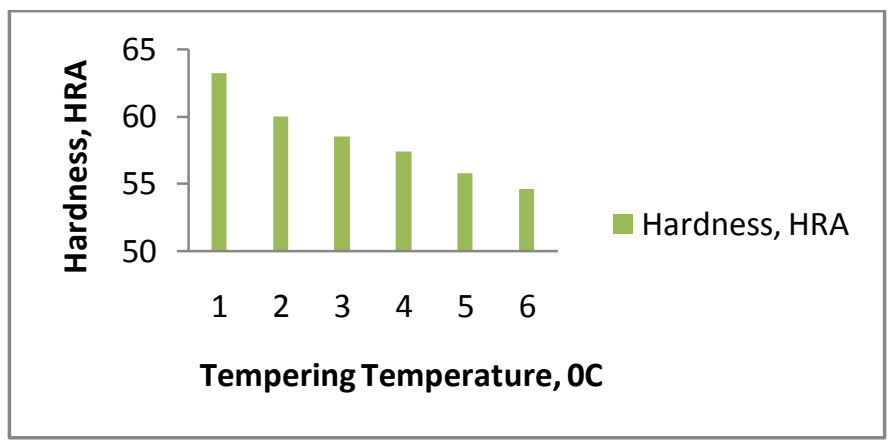

Fig. 10. Influence of the tempering temperature on hardness of medium carbon steel quenched and tempered in mineral oil.

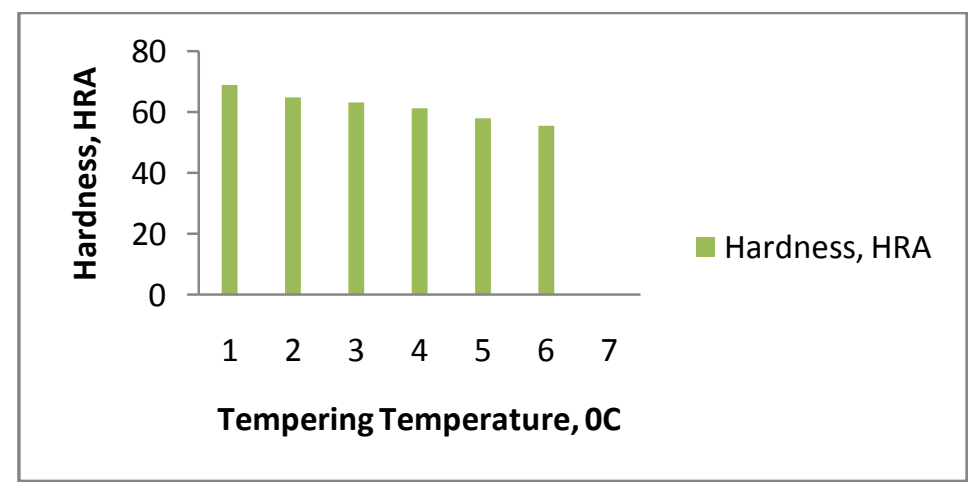

Fig. 11. Influence of the tempering temperature on hardness of medium carbon steel quenched and tempered in neem oil.

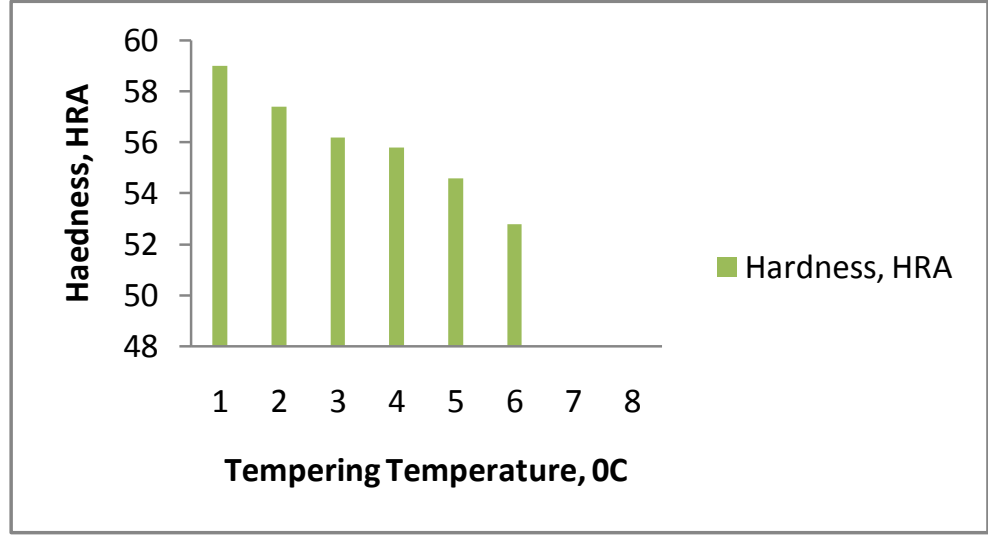

Fig. 12. Influence of the tempering temperature on hardness of medium carbon steel quenched and tempered in watermelon oil. 


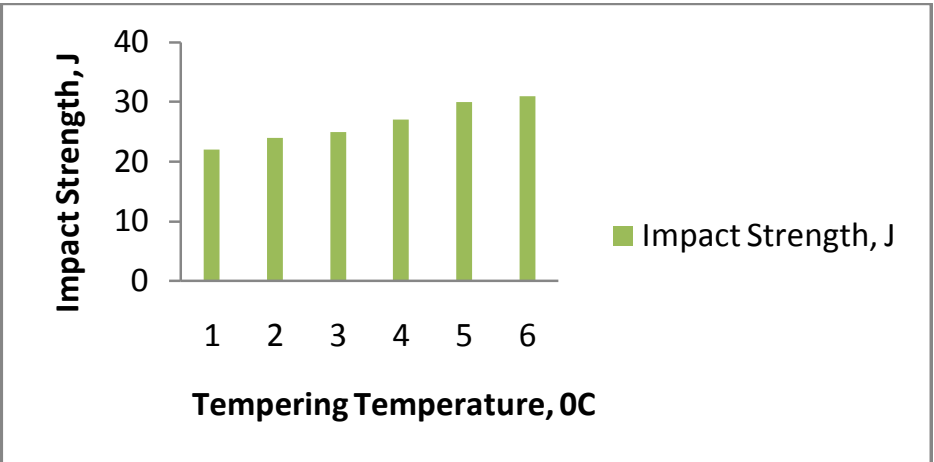

Fig. 13. Influence of the tempering temperature on impact strength of medium carbon steel quenched and tempered in mineral oil.

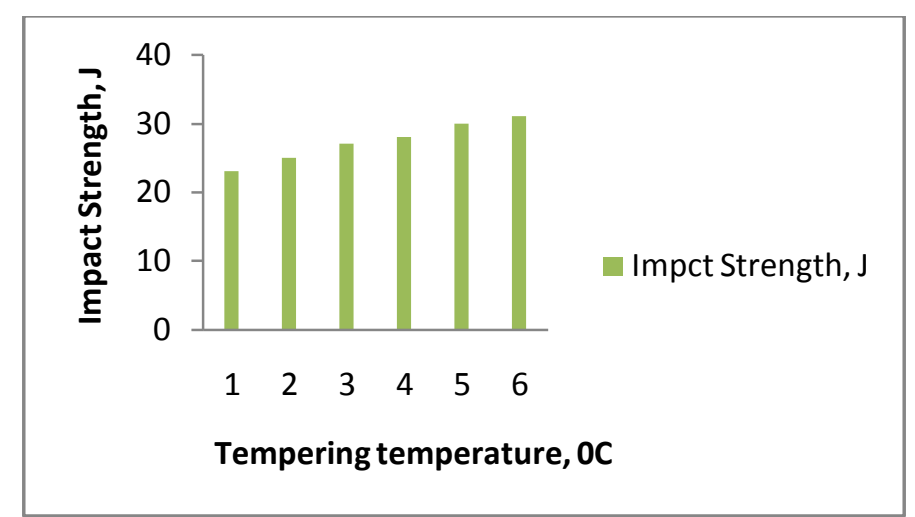

Fig. 14. Influence of the tempering temperature on impact strength of medium carbon steel quenched and tempered in neem oil.

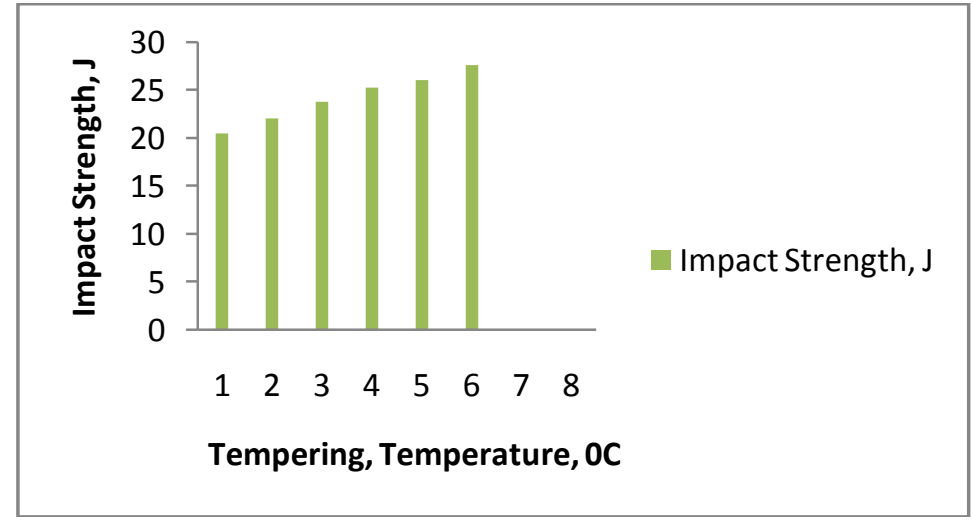

Fig. 15. Influence of the tempering temperature on impact strength of medium carbon steel quenched and tempered in watermelon oil.

\section{Conclusions}

Comparative study of neem oil and watermelon oil as quenching medium with mineral oil was conducted and the following results can be summarized as follows:

1. The mechanical properties and microstructure evolution of this steel under different tempering and austenitizing conditions have been studied.

2. The steel responds well to tempering heat treatment for all the quenchants (neem oil, watermelon oil and SEA 40 oil).

3. The results from the tensile and hardness tests indicate that tempering temperature and austenitizing temperature and effects on the mechanical properties and microstructure features indicating that under tempering conditions, the strength and hardness decrease linearly with an increase of tempering temperatures.

4. The structural behaviours are fully characterised for the steel in the quenched and tempered conditions at various tempering temperatures on both oils, is more pronounced using neem oil. 


\section{Acknowledgement}

The Authors are highly grateful to National Research Institute of Chemical Technology (NRICT), Zaria for providing neem seed oil for this research.

\section{References}

[1]. Gulyaev, (1980): Physical metallurgy; vol. 1 Mir publishers, Moscow, USSR. pp 240-301

[2]. American Society for Metals (1997):, ed. Metals Handbook. 9th ed. Vol. 4. pp. 32-35.

[3]. K. J. Pascoe, (1978): An introduction to the properties of engineering materials, Van Nostrand Reinhold Company, London. pp 273289.

[4]. Fujimura, Y., Sato, T., (1963). The composition of quenching oil and quenching effects, The Iron and Steel Institute of Japan (ISIJ), Vol. 49, p. 1008-1015.

[5]. Hassan S. B., Agboola J. B., Aigbodion V. S. Williams E. J. (2011): Hardening characteristics of plain carbon steel and ductile cast iron using neem oil as quenchant, Journal of Minerals \& Materials characterization \& Engineering, Vol. 10, No. 2, pp. 161-172.

[6]. Novokov, (1980): Theory of heat treatment of metals, Mir publishers, Moscow, USSR. pp. $361-373$

[7]. M. Philip, B. Bolton, (2002): Technology of engineering materials, Butterworth Heinemann, Great Britain, pp 45-52, 200-222

[8]. R. Dabrowski, R. Dziurka, (2011): Tempering temperature effects on hardness and impact tougness of 56NiCrMo7 steel, Archives of metallurgy and materials, Vol. 56. pp.11.

[9]. S. A. Salihu, (2011): Fundamentals of materials science and engineering, first edition, Bolt project Nig. Limited printers, Nigeria. pp 331-341

[10]. Tagaya, M., Tamura, I., (1954) Studies on the quenching media 3rd report. The cooling ability of oils. Technology Report, Osaka University, Vol. 4, p. 305-319.

[11]. Totten, G.E., Howes, Maurice A.H,(1997): Steel Heat Treatment Handbook, Marcel Dekker, Inc.

[12]. p. 157.

[13]. T. V. Rajan, C.P. Sharma, (1994): Heat treatment principles and techniques, revised edition, New Delhi, Prentice- Hall of India private limited, pp.76- 115

[14]. William D. Callister, Jr.(2007): Materials science and engineering am introduction, John Wiley \&Sons, Inc. USA. pp 387 - 402 